\title{
La grafía en la historieta: evolución de la combinación de texto y dibujo en los orígenes y primer desarrollo del cómic
}

\author{
OCTAVIO BEARES
}

Octavio Beares San Martín (Oviedo, 1970) es licenciado en Geografía e Historia por la Universidad de Santiago de Compostela, y diplomado en Restauración y Conservación de Bienes Culturales por la Escuela Superior de Conservación y Restauración de Pontevedra. Comienza a escribir sobre cómics en su blog personal, El Octavio pasajero, y posteriormente en el blog Serie de Viñetas, especializando esta bitácora del site Gente Digital en historieta. Colabora en medios digitales como Culturamas o la revista Viñetas en Palabras. Cofundó en 2012 el blog Quadriños, del diario digital Praza Pública. Ha escrito sobre historieta en medios impresos (puntualmente en Guía Cicerone y Xornal de Galicia, en Rockdelux entre 2011 y 2012) y desde 2009 realiza una sección quincenal sobre cómic en Faro de Vigo, donde también colabora como crítico de música. Participa en el magacín "A estación”, de Radio Redondela, hablando de tebeos. Ha organizado los Primeiros Encontros coa banda deseñada. O cómic no museo, para el Museo de Pontevedra, en 2012. Codirige CuCo, Cuadernos de cómic.

\section{RESUMEN}

Proponemos en el presente estudio una aproximación a uno de los fenómenos más característicos de la historieta: la inclusión de letra escrita en un contexto de narración gráfica. Se trata de un estudio que aborda una perspectiva cronológica de la historia del cómic desde sus primeros pasos hasta la consolidación y popularización del medio como referente cultural mass media (años treinta del siglo XX). Nuestra intención es analizar el nacimiento e implantación de una relación entre grafía e ilustración que tiene en la historieta un caso único, dentro del mundo de las artes.

\begin{abstract}
The present essay purposes a studio of one of most characteristic signs of comics: the mixing of drawings and letters into a context of graphic narrative. This work is a
\end{abstract}

CuCo, Cuadernos de cómic número 1. Septiembre de 2013

CuCoEstudio 
chronologic study of the history of comic, beginning in its early first stepts and ending in 30's, the decade of mass media recognition for comics. Our intention is the analysis of a process: the birth and implantation in a historic process of a relationship in between letters and illustration. An unique case in all arts.

\section{Introducción}

Puede resultar curioso al lector que comience presentando mi trabajo proponiendo una contradicción. Frente a una máxima que define a la historieta como un arte híbrido de letra y dibujo, soy de la opinión de que no es una aseveración del todo justa con el cómic como medio. No cabe desarrollar ahora dicha cuestión, pues será explicada a lo largo del presente texto, pero sí aclarar que veo más esencial como elemento definidor la capacidad narrativa de la propia imagen que no la necesidad de que esta se combine con letra escrita.

Sin embargo trataré en este trabajo, precisamente, la historia de un amanecer y primer desarrollo en el arte del cómic que vinculo a una evolución en la interacción de la letra y las ilustraciones en la historieta, cual si la naturaleza del medio pudiera ser dependiente de dicha mezcla. Bien, pienso que la esencia realmente sustancial y profunda del cómic es una cosa muy distinta a la realidad de su crecimiento, y por eso no cabe hablar de paradoja. De un modo objetivo debemos reconocer que la evolución del medio ha ligado, desde sus orígenes, a dos polos en apariencia opuestos como son la letra y la escritura, de la ilustración o la representación de la realidad a través del dibujo secuenciado. ${ }^{1} \mathrm{Y}$ de esa ligazón primigenia deriva buena parte de la riqueza del llamado noveno arte.

Este es el campo de estudio que nos proponemos aquí, que deriva de esta mezcolanza en absoluto contra natura.

\footnotetext{
${ }^{1}$ La idea de que el cómic se caracteriza por la disposición de varias estampas ordenadas con la intención de crear una secuencia lineal, temporal, en una estructura de narración elíptica mediante sucesión de imágenes también es muy común. Pero la realidad es que existen experiencias de historieta no secuencial que demuestran las muchas posibilidades, aún por explotar, del cómic como medio narrativo.
} 
En otro orden de cosas, hay que hablar sobre la naturaleza de las imágenes seleccionadas. Mi preferencia en principio era buscar ejemplos en su idioma original. Si interesa plantear como muestras instructivas aquellos cómics que sean originales es, evidentemente, porque se intentan analizar las características de una letra que poseerá condición icónica, de dibujo, como se verá a lo largo del estudio. Y lo mejor es, entonces, acudir al original, a la obra en su propio idioma. Es pertinente reflejar las grafías reales, antes que los esfuerzos, a veces más que notables, por traducir y reescribir al castellano dichos textos. ${ }^{2}$

También soy consciente de una omisión durante todo el presente texto que merece ser citada, ya que se trata de un cómic sin duda muy popular: el manga japonés posee evidentemente una caligrafía que nos es ajena, un modo de escritura de iconicidad tan propia como exótica a nuestra mirada, cuyos valores intrínsecos no podemos comprender completamente. Tampoco, por eso mismo, entiendo útil acudir a versiones traducidas de tebeos nipones, con alfabeto occidental. Las diferencias entre la letra oriental y la latina resultan excesivamente grandes como para imaginar que lo que se traduce traslada correctamente todos los efectos (en tanto que grafema y en tanto que dibujo) del original japonés (forma, tamaño, disposición en la página de los textos, etc.). $\mathrm{Y}$ en caso de centrarnos en ejemplos originales, la intencionalidad de dicha grafía nos permanecerá oculta, o peor, nos podría resultar equívoca al desconocer dicha lengua y su particular escritura. Aunque en ocasiones me creyese capaz de discernir no pocos ejemplos por su contexto y dada la universalidad de los recursos del cómic, no deja de ser un atrevimiento aventurado que prefiero descartar metodológicamente.

En definitiva, con este recorrido veremos que, incluso centrando nuestra atención en un único aspecto de los muchos que pudieran ser estudiados en relación a la narración gráfica, tal es la riqueza histórica y formal del noveno arte que quedará

\footnotetext{
${ }^{2}$ Es cierto que en ocasiones podría ser más eficaz el empleo de traducciones, en tanto que sea pertinente la comprensión de lo escrito para su análisis, pero no lo he considerado necesario en el presente trabajo. Veremos en futuros ensayos la pertinencia de sacrificar la versión original en aras de apoyar nuestro discurso teórico.
} 
revelada su naturaleza compleja y, para quien firma, apasionante e inagotable. El cómic, la historieta, es un campo vasto en el que perderse, un crisol donde, confluyendo ilustración, literatura, pintura, diseño y otras disciplinas, de la amalgama surgió allá en la era de la máquina de vapor un arte nuevo. Hoy aún se muestra vital, pleno de posibilidades y asentado sobre unas bases que lo hacen digno de estudio. Comencemos pues.

\section{Evolución de la combinación de texto y dibujo en los orígenes y primer desarrollo del cómic}

Podría parecer, aunque solo sea por argumentos cuantitativos, que por cómic cabe entender la narración impresa donde texto e imagen se combinan en una secuencia, generalmente de orden temporal, a los efectos de transmitir una historia. $\mathrm{O}$ algo parecido. Pero la realidad es que el empleo de palabra escrita no debe entenderse como algo intrínseco o un elemento necesario para completar la naturaleza de la historieta. En la FIG.1 podemos "leer" dos páginas que carecen de letra alguna: la secuencia discurre visualmente y no precisa de textos para su completo entendimiento.

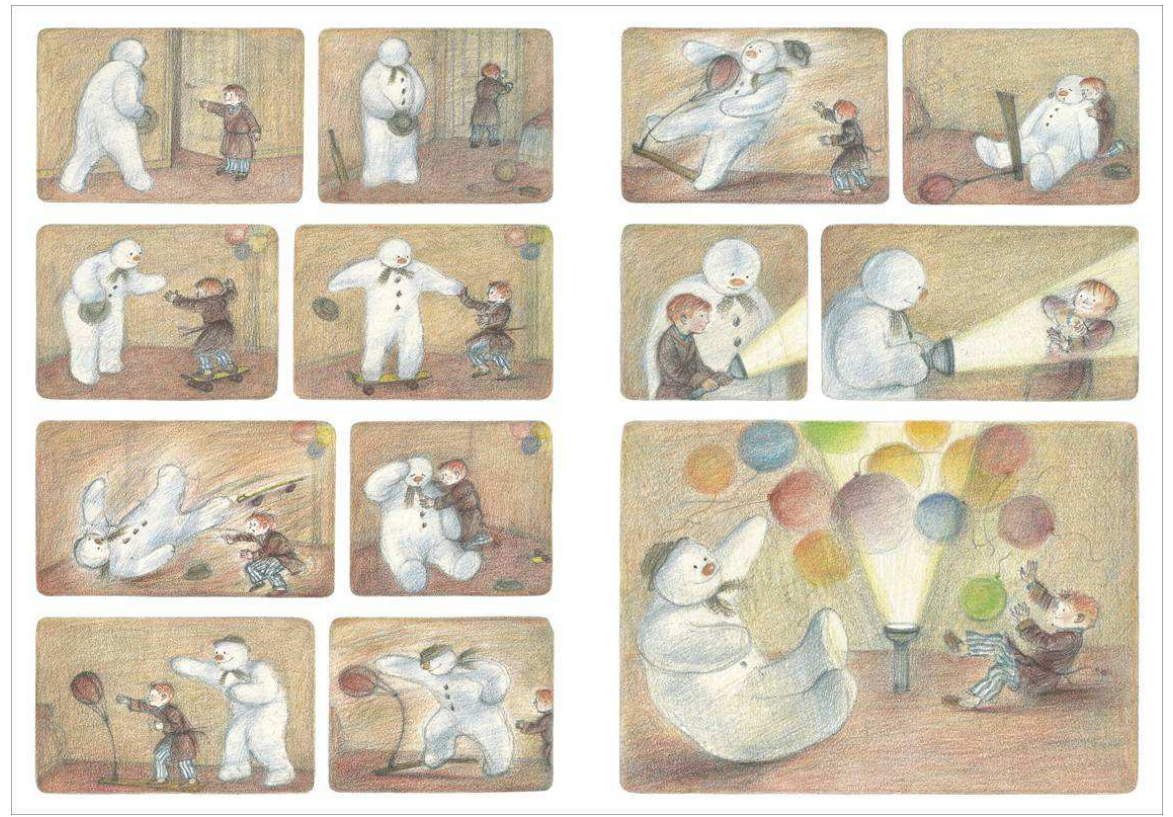

FIG. 1. El Muñeco de nieve. Raymond Briggs, 1978.

CuCo, Cuadernos de cómic número 1. Septiembre de 2013 
Este ejemplo, además, pertenece a una obra carente por completo de elementos de escritura. Crear un cómic con estas características no es una decisión arbitraria en absoluto, pues su autor busca deliberadamente un determinado tono narrativo. Estas páginas y cualquier otra de la misma obra, El muñeco de nieve de Raymond Briggs (1934), son un caso claro de tebeo desarrollado con imágenes dibujadas, sin intervención de la grafía.

La narración en imágenes sucesivas sin el apoyo de textos no es frecuente, cierto, si bien tampoco resulta exótica. No ya en historietas totalmente sustentadas por una historia que prescinde de la palabra escrita para su desarrollo, sino en numerosos casos que buscan cierto efecto dramático de la imagen pura en la planificación de una secuencia. Por ejemplo, en el inicio de Verano Indio, de Hugo Pratt (1927-1995) y Milo Manara (1945), que vemos en la FIG. 2 y que es el arranque de unos sucesos que suponen seis páginas silentes, en total. Se narra aquí el ataque por parte de unos jóvenes amerindios a una muchacha de las colonias, y las inmediatas consecuencias de dicha acción. Esta escena, sin presencia de lenguaje textual y apuntalada en lo puramente gráfico, expresa con su planificación, sus contrapicados, y por supuesto con su ausencia total de grafías, una atmósfera trágica.

El incorporar o no la escritura a una determinada escena en un tebeo, por tanto, será antes una opción narrativa que un elemento definitorio. 

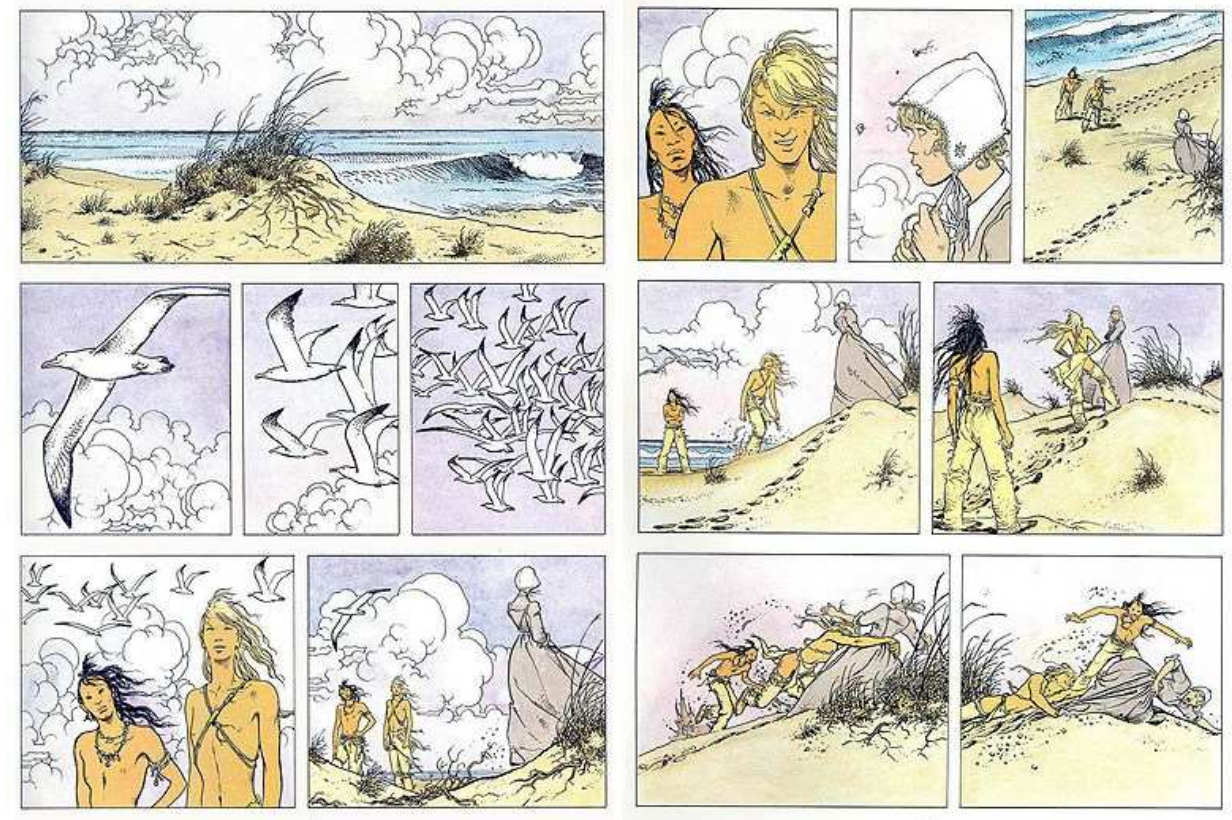

Fig. 2. Verano indio. Hugo Pratt y Milo Manara, 1986.

En este sentido, y sin ánimo de extenderme más allá en este punto ni de ofrecer más ejemplos al respecto, hay que concluir que la esencia de la expresión comicográfica $^{3}$ se encuentra en la capacidad narradora de la imagen, y en mayor medida en la de la sucesión de imágenes en secuencia ordenada. No, pues, en la mixtura de letra escrita y dibujo. Pero si atendemos a los hechos históricos vemos que en el ánimo de crear unos parámetros del método narrativo de la historieta, desde sus inicios en el siglo XIX la grafía se ha imbricado con la ilustración y el dibujo secuenciado.

Es natural, podemos llegar a sentenciar, en tanto que el cómic es ante todo un artefacto de narración derivado primigeniamente del humor gráfico de prensa. ${ }^{4}$ Los

\footnotetext{
${ }^{3}$ Término acuñado por Rubén Varillas (VARILLAS, R. El cómic: texto y discurso. Una propuesta de análisis narratológico. Salamanca, Ediciones Universidad de Salamanca, 2007). Varillas lo define en su tesis como un "adjetivo creado por su afinidad con términos similares dentro del mundo de las artes narrativas visuales (fotografía > fotográfico, cinematografía > cinematográfico, etc.)" (VARILLAS, R. Op. Cit., p 33).

${ }^{4} \mathrm{O}$ incluso de experiencias anteriores, aunque también ligadas al auge de la imprenta, como las series de grabados de William Hogarth, predecesor de la narrativa gráfica con sus Moral modern subjects, iniciadas en 1732. Para una mayor aproximación a los logros de Hogarth, cf. ALTARRIBA, A. Los inicios del relato en imágenes. los grabados de William Hogarth. Vitoria, Comisión de Álava de la Real Sociedad
}

CuCo, Cuadernos de cómic número 1. Septiembre de 2013 
autores que en las primeras décadas del siglo XIX pergeñaban lo que sería la historieta como un modelo autónomo y único de transmitir historias, lo hicieron empapados de su propia cultura y su propio momento histórico. Hablamos de la era industrial, la del nuevo urbanismo y del auge de una prensa de distribución masiva, en la que fue muy popular la chanza, la ironía y la denuncia política o social a través de la comicidad de la viñeta satírica. Y la viñeta satírica mezcla para sus propios fines lo dibujado con lo escrito, dando un claro modelo para los autores que, como Richard F. Outcault o Rodolphe Töpffer algunos años después, pretendían otras metas, ajenas a la mofa cáustica propia del humor gráfico de los diarios.

Es pertinente introducir la figura del suizo Rodolphe Töpffer (1799-1846), autor del ejemplo de la FIG. 3. De oficio maestro, fue profesor de retórica en la Academia de Bellas Letras de Génova y llegó a fundar su propia escuela en 1825, el dibujante buscaba una forma de realizar cuentos para sus alumnos, desarrollando historias de una página, ideas y narraciones que no cabrían en una sola imagen cómica. Sus balbucientes tebeos se plasmaron en libros desde 1827, volúmenes que recopilaban historias gráficas como Histoire de Mr. Vieux-Bois, de ese mismo año, donde además de imágenes consecutivas enmarcadas en viñetas observamos la utilización consciente y metódica de didascalias. Dicho recurso consiste en textos que, bajo cada imagen dibujada, la complementa describiendo la acción y añadiendo contenido a lo expresado icónicamente por medio del dibujo. Una historieta de Töpffer no se entiende del todo sin leer los textos de apoyo, pareados descriptivos de una acción. Pero tampoco puede comprenderse obviando las ilustraciones que acompañan a esas cartelas de texto, pues son la plasmación definitiva de dichos actos y la representación de los mismos sobre el

Bascongada de los Amigos Del País, 2006. Disponible on line en
http://www.tebeosfera.com/documentos/textos/los inicios_del_relato_en_imagenes_los_grabados_de_wil
$\underline{\text { liam_hogarth.html }}$

CuCo, Cuadernos de cómic número 1. Septiembre de 2013

CuCoEstudio 
papel. Es un primer signo del entendimiento, desde su origen como arte, de la letra y la imagen en el cómic. ${ }^{5}$

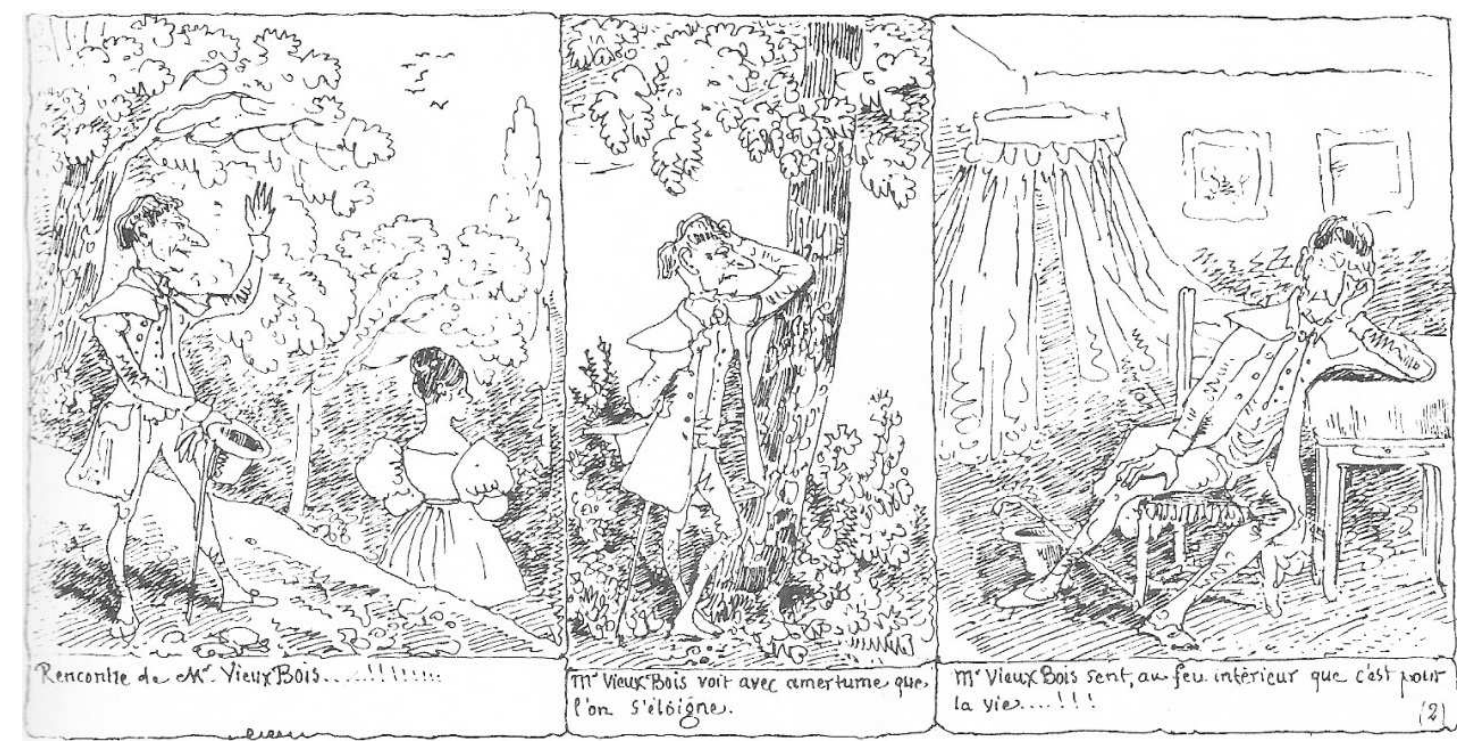

FIG. 3. Les amours de Mr. Vieux-Bois. Rodolphe Töpffer, 1827.

En esta misma época encontraremos otros ejemplos donde además comienzan a producirse los primeros personajes fijos. Esto es, aparece un protagonista de la acción, que lo será de sucesivas historias relatadas con posterioridad. La identificación por parte del lector de un personaje, un carácter reconocible y familiar, será otra característica importante del medio ya desde los primeros pasos de la historieta, al llevar a primer término el elemento comercial que se une al cómic desde sus inicios. Como historias populares que se reproducirán en diarios o en revistas, ${ }^{6}$ los tebeos empiezan a explotar el gancho del personaje fijo. Así cabe citar Max y Moritz del alemán Wilhelm Busch (1832-1908), nacida en 1865, y donde los textos de apoyo vuelven a ser un elemento de

\footnotetext{
${ }^{5}$ Se puede señalar para apreciar la consideración de estas nuevas y emergentes formas artísticas, que el propio Rodolphe Töpffer mostraba escaso interés u orgullo personal hacia su hallazgo, ya que su afán era convertirse en un reconocido escritor literario. Aunque efectivamente lo tentó, escribiendo obras como $\mathrm{La}$ Bibliothèque de Mon Oncle (1832), la creciente fama de su obra historietística y la reafirmación popular del cómic como forma artística, asocian hoy su nombre, indeleblemente y para su mayor gloria, al de los grandes pioneros de la historieta, cuando no se lo cita directamente como creador del noveno arte.

${ }^{6}$ El periódico fue el seno para el cómic en Estados Unidos, siendo Europa más receptiva al fenómeno de las revistas, con cabeceras como Comic Cuts en Gran Bretaña, nacida en 1890 y que aglutinaba diversos títulos de historieta combinados con relatos literarios para infantes.
}

CuCo, Cuadernos de cómic número 1. Septiembre de 2013 
narración asociado a las estampas secuenciadas en el estilo acuñado por Töpffer. Ahora en un tebeo sobre las travesuras de dos niños hermanos, uno rubio y otro moreno. ${ }^{7}$ Otro ejemplo de textos didascálicos tempranos es el de la obra del catalán Apeles Mestres ${ }^{8}$ (1854-1936), y la lista de nombres propios podría extenderse. Lo interesante para este estudio, en fin, será determinar cómo en sus inicios el desarrollo de la imbricación de lo textual en la página dibujada supone un tanteo, por parte de todos estos pioneros del cómic, y que al tiempo, como ya he apuntado, parte de modelos pretéritos.

Ciertamente hay que reconocer que la combinación de didascalias con ilustraciones para conformar un relato no es nueva, y podremos rastrearla en el ya citado artista británico William Hogarth (1697-1764) o también en los romances de ciego del siglo XVII o en las Aleluyas mediterráneas, que se datan hasta el temprano siglo XVI, como por ejemplo el Libro del juego de las suertes (1528) del impresor Juan Joffre. Sin embargo hay que matizar que no hablamos, en estos casos, de cómic ni de proto-cómic, sino de un claro precedente. ${ }^{9}$ El ser humano es de naturaleza comunicativa, y los elementos para comunicarnos de un modo perdurable son en cierto modo recurrentes. Más antiguo que la escritura es, y puede rastrearse, el afán por contar historias y transmitir mensajes con imágenes. Incluso con imágenes dispuestas en secuencia lógica,

\footnotetext{
${ }^{7}$ Ciertamente Max y Moritz supone la fundación de un prototipo que nos es muy cercano, el de los niños traviesos, con un famoso sucesor español, Zipi y Zape, de Josep Escobar (1908-1994), que creó la serie en 1948 para la editorial Bruguera.

${ }^{8}$ Apeles Mestres es considerado uno de los pioneros del cómic español, ya que Un enterro a la montanya, publicada en 1786 en La llumanera de Nova York, puede situarse como uno de los ejemplos tempranos de historieta patria.

${ }^{9}$ Antonio Martín define las aleluyas. MARTín, A. "Historia de las lecturas infantiles. Las aleluyas (Primera lectura y primeras imágenes para niños (siglos XVIII-XIX)", en CLIJ, no 179 (Febrero de 2005): "En las aleluyas hay una lectura de las imágenes y paralelamente una lectura de los textos que las apoyan. Así evolucionan desde su primer estadio como juego o como catálogo de imágenes curiosas o exóticas, con cierto valor didáctico, al más complejo de una historia que se narra a través de una síntesis de imágenes aisladas - que implica un importante esfuerzo de elipsis, tanto en los autores como en los lectores - en las que se recogen una serie de momentos significativos de la biografía, el relato o la novela que constituye el tema de las viñetas de la aleluya." (MARTín, A. Op. Cit., p. 52). Y añade: "En cualquier caso no hay que exagerar la importancia del valor narrativo del lenguaje expresivo de las aleluyas, ni forzar la argumentación para presentarlas como el paso inmediatamente anterior al cómic (...) En realidad, la secuencia narrativa de la aleluya es muy primitiva." (MARTín, A. Op. cit., p. 53).
}

CuCo, Cuadernos de cómic número 1. Septiembre de 2013 
bien comunes en la historia del arte, desde las pinturas del Imperio Egipcio a las predelas de retablos góticos. Muchos de esos recursos serán aprovechados en el nuevo vehículo transmisor de historias para las masas en el siglo XIX.

Por eso no nos debe extrañar el ejemplo de la FIG. 4, estampa satírica dibujada y escrita por Thomas Rowlandson (1756-1827). Data de 1784 y en ella apreciamos todos los elementos que se repetirán en la historieta: didascalias o cartelas, globos o bocadillos... muchos de ellos, evidentemente, aprehendidos de la tradición de la historia del arte, como hemos señalado.

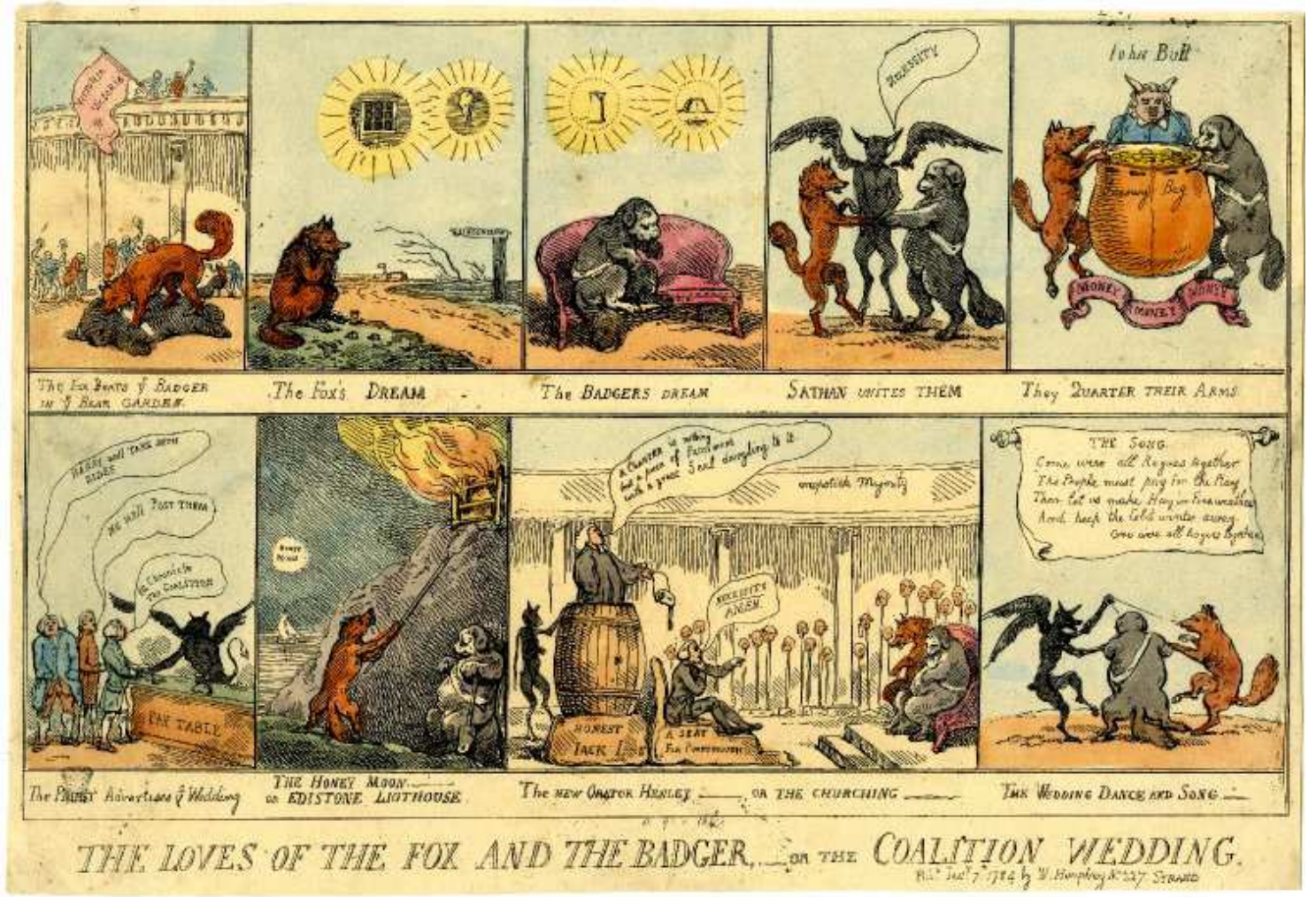

FIG. 4. The loves of the fox and the badger. Thomas Rowlandson, 1784.

El globo o bocadillo, lo vemos aquí, es una figura geométrica, habitualmente una esfera, de la que brota alguna suerte de elemento direccional (un hilo, un rabillo...) y que contiene en su interior un texto que los lectores debemos entender como un diálogo. De este modo se referencian las palabras concretas que emite un personaje determinado, representado en la estampa o que actúa fuera de campo. Hoy es habitual ver globos de 
diálogo y a nadie se le escapa su significado, sin embargo el concepto precisa de un proceso mental elaborado para poder asimilarlo, si no tenemos el recurso de la experiencia y el conocimiento. Si trasladamos esta idea a la historia del cómic, evidentemente ese proceso mental consistirá en la búsqueda de fórmulas para expresar las palabras de personajes representados icónicamente, y encontrar el mejor modo de hacerlo no es sencillo. De hecho ha sido una evolución creativa de siglos de historia del arte. $^{10}$

Pero volviendo al tebeo de Töpffer, y entendiendo que la historieta nace híbrida y de elementos preexistentes, no es menos verdad que lo hace para un tiempo nuevo. En este sentido de su mezcla de escritura y dibujo resulta también algo diferente, donde el empleo de la letra irá más allá de lo funcional o lo accesorio para convertirse en objeto prioritario. A partir del autor suizo se puede apreciar, en los venideros autores de historieta, un camino de refinamientos formales, con una evolución imparable. Podemos decir que lo pragmático, tomar elementos de narración previamente tanteados en la historia del arte porque así se podrá contar una historia, se convierte en lo primordial: se da a la reformulación de esos ardides una nueva naturaleza estética y también narrativa.

Hoy podemos ver que los historietistas de fines del siglo XIX y principios del XX, cada vez con mayor consciencia a medida que los cómics se instauran y normalizan, entendían la combinación de letra con imagen secuenciada como el germen de un medio de comunicación nuevo. Un oficio ligado a los nacientes mass media, al auge del periódico y las revistas que eran producidas, distribuidas y finalmente consumidas en masa por un nuevo espectro social (burguesía, proletariado, etc.). Un arte nuevo, en definitiva, para un hombre nuevo, contemporáneo, que disfruta en sus diarios o revistas de esas historias que se ven y se leen, a medio camino de las estampas y de la escritura.

\footnotetext{
${ }^{10} \mathrm{El}$ arte ha representado el acto de hablar en numerosas ocasiones; por ejemplo, no es inhabitual en escenas góticas de la Anunciación poder leer las palabras del arcángel en una filacteria que nace de su rostro o sus manos. Buen ejemplo es en el Retablo Mayor de San Miguel (Anento, Zaragoza), del Maestro Blasco de Grañén (pintor documentado entre 1422 y 1459), en la tabla de la Anunciación, o la del Profeta David.
} 
Los primeros autores potenciaban el uso de letra escrita porque es práctico y ya ensayado, como vimos. El fin último de la natural convivencia de grafía e ilustración es la legibilidad del conjunto como un todo, y en este sentido las primeras rotulaciones, ${ }^{11}$ sean manuales o de imprenta, apenas atienden a un axioma único: lo escrito debe ser claro y de fácil lectura. El cómic naciente quiere penetrar en un mercado, es un nuevo artefacto narrativo y esta balbuciente historieta aún no se plantea aspiraciones autorales. Recién nacida, no es su prioridad, ni posee la consideración elevada de una bella arte, para pretender esa ambición artística que sí suponemos al cómic hoy por hoy. Muy al contrario, se entiende como un producto de consumo, busca al lector y a cuantos más lectores mejor, y los quiere fidelizar. Pero como toda disciplina creativa, los nuevos autores irán haciendo de su obra un lugar de tanteos, experimentos y hallazgos.

Richard F. Outcault (1863-1928) es tenido, en los Estados Unidos de América, como uno de esos tanteadores. De hecho, se lo señala como el padre verdadero de la historieta. Lo dudo, y otros muchos también dan por desfasada semejante aseveración ante la realidad de autores anteriores, como los aquí citados y otros muchos. Pero hay que reconocer la magnitud de la figura de Outcault, y otorgar todo merecimiento a la fama mundial de su tira The Yellow Kid and his new phonograph, publicada en 25 de Octubre de 1896 en el diario Journal, concretamente en su suplemento dominical American Humorist (FIG. 5).

\footnotetext{
${ }^{11}$ Ahondaremos en el concepto de la rotulación en el siguiente capítulo, pero quede apuntado que por rotular debe entenderse la acción de escribir y dibujar palabras en la página de historieta.
} 


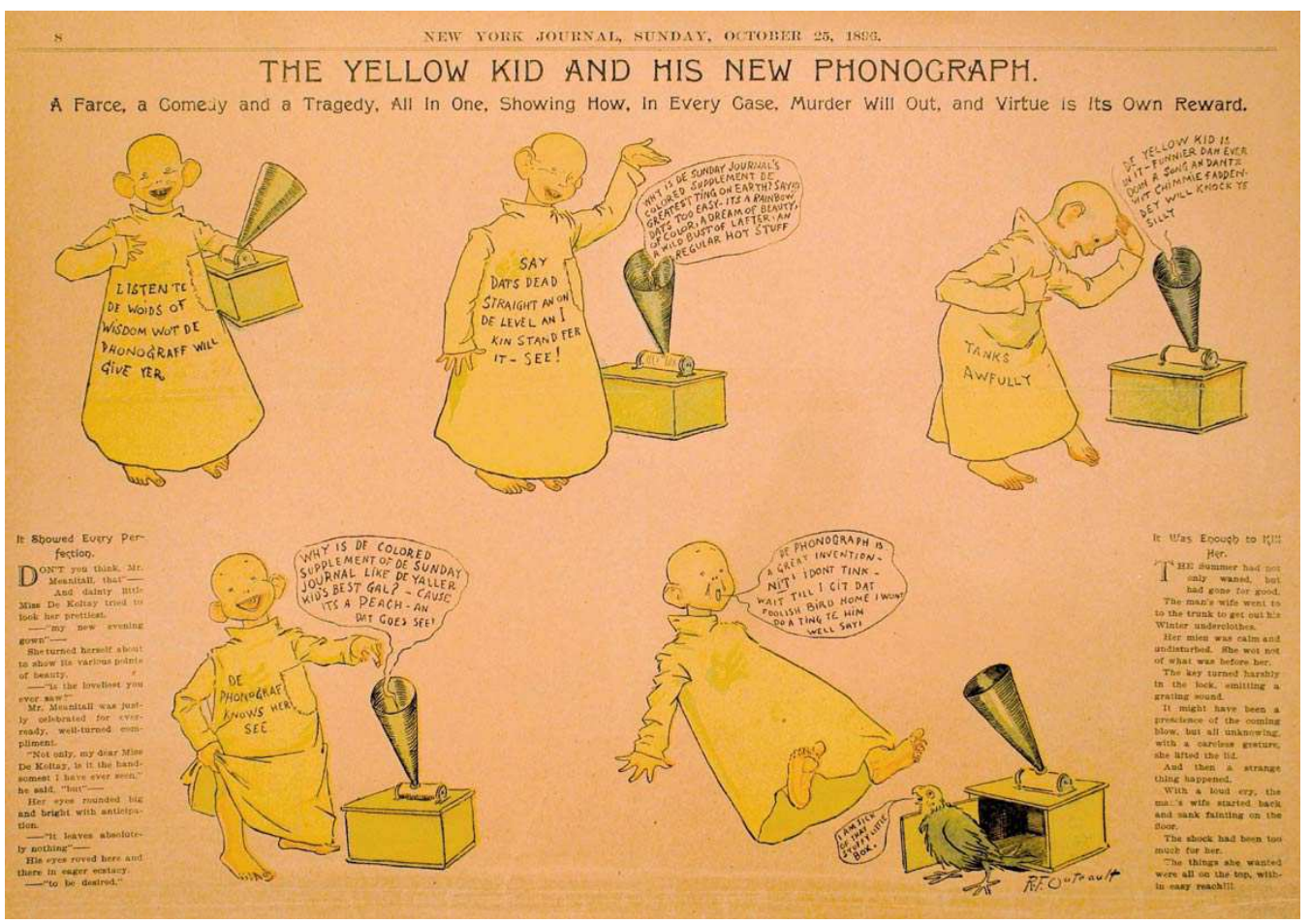

FIG. 5. The Yellow Kid. Richard F. Outcault, 1896.

El Niño Amarillo había nacido en 1888, pero consistía en una suerte de tableau, una gran escena única donde a su vez se desarrollaban diferentes situaciones, siempre con un personaje fijo y protagonista, un niño barriobajero que lucía un camisón amarillo sobre el que se leían mensajes escritos a modo de ideas, pensamientos o sentencias. Curioso efecto que antecede quizá al monólogo interior en el cómic moderno, pero que no se acompañaba de otros recursos como la secuencia o los globos de diálogos. Todos ellos sin embargo sí aparecen perfectamente conjuntados en la tira del fonógrafo. En ella el personaje es protagonista de una historia explicada en dibujos sucesivos, en la que se asusta ante la habilidad de su reproductor de discos para hablar. Pero sorprendido descubrirá qué es lo que realmente está ocurriendo, cuando en la última imagen (viñeta si se quiere, si bien carente de marco), de la caja sale un loro parlanchín que se escondía en su seno. Todo ello se nos explica haciendo una mezcla refinada (más para su tiempo, más aún si la entendiéramos como pionera) de personaje fijo, imagen secuencial, cartelas, bocadillos y por supuesto los citados textos inscritos en el camisón del crío. 
En la segunda parte de este trabajo nos centraremos en explicar, entre otras cosas, los diferentes modos y lugares en que la letra escrita recibe cobijo dentro de la historieta, pero quedan iluminadas las principales, sin duda, en este ejemplo temprano. Desde aquel 1895 han pasado muchas cosas, pero no todas inmediatamente: ni otros autores ni el propio Outcault parecieron ser conscientes del logro formal alcanzado con la anécdota del loro y el niño. Acaso porque, en realidad, todos estos elementos existían ya, separadamente o en diversas combinaciones, y la falta de perspectiva impedía comprender que The Yellow Kid and his new phonograph lograba una acertada y completa conjunción. La reacción no fue inmediata en el mercado norteamericano, incluso el propio Outcault volvió a sus formas anteriores, pero evidentemente llegó, y pronto el cómic se presenta totalmente desarrollado, en obras como Little Nemo en Slumberland de Winsor McCay (1869-1934).

Outcault dejó de dibujar su Niño Amarillo en 1898, Winsor McCay, que inició su carrera como autor de tebeos dos años antes, en 1896, comenzó las andanzas del Pequeño Nemo en 1905. Siete años los separan, pero el arcaísmo de la sorpresa fonográfica ha desaparecido totalmente en las planchas asombrosamente actuales de McCay. Bien es cierto que la figura de este autor nacido en Michigan se cuenta como la de uno de los mayores maestros de la historia del cómic, pero también es evidente que en la era de la velocidad y las nuevas comunicaciones, la naciente historieta se hace plenamente autoconsciente en unos pocos años. Con Little Nemo encontramos la mayor parte de los recursos historietísticos ya maduros, en sus páginas todo recurso resulta pleno y refinado. Podemos aprender qué es una historieta leyendo las aventuras de Nemo, disfrutando además de una experiencia visual asombrosa y de una elegancia narrativa superior a la de muchos de sus coetáneos.

Cada plancha de este cómic era una historia del niño protagonista en Slumberland, “el País de los Sueños”, con plasmaciones de una grandiosidad y detallismo inigualado, pero que terminará siempre con una pequeña y discreta viñeta donde Nemo despierta en su cama. Todo es fantaseado, pues, en las maravillosas, pre-surrealistas aventuras del pequeño muchacho. 
En las historias soñadas por el niño Nemo podemos apreciar que a principios del siglo XX el cómic ya entiende el papel estético de la letra escrita como imagen visual. Más allá de la idea de utilidad que vemos en los anteriores ejemplos, pronto los dibujantes de historietas comprenden que la grafía es también dibujo. La FIG. 6 propone una plancha de Little Nemo en Slumberland de 1905.

En ella asistimos a uno de tantos disparates soñados: un gigantesco pavo arranca del suelo una vivienda, y de ella cae el niño hasta un "lago de rica salsa de arándanos", citando a la propia obra. Bien, así son las imposibles historias de esta fantasía, pero lo que nos atañe es comprobar cómo McCay ya utiliza de un modo muy consciente la inserción de variados modos de letra escrita. En 1905, y en Little Nemo en Slumberland, la noción estética de la letra dentro del noveno arte es ya un hecho. Lo podemos comprobar en el ejemplo. Por un lado abundan las didascalias, con la curiosidad de que cada una (siempre y como es habitual en los primeros tiempos de la historieta bajo su correspondiente viñeta) está precedida por un número que ordena la lectura y la facilita. Si la diagramación ofrece un cuidado e ingenioso esquema compositivo, con la imagen principal en una viñeta circular presidiendo la escena, es cierto que con ello la dirección de la lectura, el orden de la secuencia, podría resultar confuso. Al numerar las didascalias no cabe dudar al respecto y el lector no se pierde en el orden de la lectura, gracias al empleo de los cardinales. 



FIG. 6. Little Nemo en Slumberland. Winsor McCay, 1905.

Pero hay más elementos dignos de interés: el primero es la intencionalidad y consciencia del autor a la hora de rotular, ya que los diálogos de la obra poseen una grafía diferenciada de la de las cartelas, en mayúsculas estas. Además, es evidente el grado de compenetración que se establece entre los distintos elementos gráficos y 
textuales si atendemos a cómo el autor dispone la didascalia que explica el óvalo central, pues esta mantiene y respeta la naturaleza curva de esa estampa. Porque no solamente se trata de una viñeta de forma oval, sino que lo representado en su interior, la ilustración del enorme pavo con su cola y su buche, la luna al fondo, incluso el reloj bien iluminado del campanario en medio de la ciudad nocturna, muchos son los elementos esféricos de la viñeta. El "dibujo" de la frase explicativa respeta esta idea, pues es la única en toda la página en que el trayecto visual del párrafo es curvo.

Estamos en las primeras décadas del siglo XX. Las historietas ya son parte del mundo moderno, son leídas masivamente en prensa diaria y revistas. Sus códigos son reconocidos y comienzan a ser asimilados, tanto por los lectores como por los autores. Y uno de esos códigos, evidentemente, es el empleo de letra escrita que se entiende en su papel gráfico-narrativo, y por tanto como un elemento más de la composición visual de la viñeta y de la página. Elemento visual que narra, no solo por lo que dice esa letra, sino por su lugar en la página y por su propia forma, su caligrafía. En este sentido, si comparamos la obra de Töpffer o incluso la de Outcault, por acudir a algún ejemplo previo, con la FIG. 7, comprobamos cómo la sensibilidad del autor de cómics ha evolucionado rápidamente. La imagen corresponde a una plancha de Krazy Kat del 2 de Julio 1916. Su autor es George Herriman (1880-1944) y atendiéndole seguimos entre pioneros y sus obras maestras. La conocida "Gata Loca". ${ }^{12}$

Herriman domina los recursos de la narración comicográfica, la composición de la página y el papel de cada uno de los elementos propios de la historieta, con los que se atreve a jugar y probar novedosos e inventivos recursos. En este sentido podríamos citar la imaginación que aplica en las diagramaciones de cada plancha como elemento gráfico unitario y como componente fundamental de la narración, rítmico en cierto sentido; o el carácter marcadamente simbólico de su dibujo, reducido a lo esencial; o la imaginación

12 Aunque "Gata Loca" es una inexacta traducción, pues Herriman, muy conscientemente, jamás esclareció si el sexo de su felino era masculino o femenino. Algo que la lengua inglesa, al no anticipar el género en el sustantivo, ayuda a potenciar. Además, si traducimos literalmente al inglés Gata Loca escribiríamos Crazy Cat, frente al empleo de la letra "K" que elige el autor: Krazy Kat. 
del dibujante, que eleva sus espacios narrativos al grado de lugares oníricos. También su refinada caligrafía es algo a destacar y atender. Al igual que los dibujos de sus caracteres antropomórficos son básicos, planteados con economía de trazos pero dotados de plasticidad y dinamismo, la rotulación potencia sensaciones análogas, con un estilo de escritura enormemente vivaz, de trazo levemente sinuoso, muy "icónico". Entrecomillamos, porque hay que insistir en este hecho: la letra, ya plenamente concebida como parte consustancial del dibujo, y en tanto que elemento dibujado, posee propiedades expresivas previas al significado de las palabras. La grafía que Herriman diseña y escribe (rotula, dibuja) aporta un tipo de información específico, que es anterior a su significado. En resumen, es mensaje previo a la propia lectura por su forma, tamaño y disposición.

Además, cuando ocupa espacios concretos como globos o filacterias dicho dibujo de las palabras se plasma cuidando espacialmente el todo armónico que es la combinación letra-espacio contenedor (por ejemplo una línea de diálogo dentro de un globo). Redunda este hecho en el cuidado gráfico que Herriman pone en la rotulación entendida como elemento visual, uno más de los que la página presenta al lector. Se cuida la rotulación, por tanto, porque como dibujo ${ }^{13}$ emite en sí misma un mensaje, y porque como "dibujo" es parte gráfica del todo que es cada plancha y busca una armonía visual.

\footnotetext{
${ }^{13}$ La caligrafía dentro de un cómic debe entenderse también como dibujo: forma parte del todo visual que es la página, integrándose con los demás elementos visuales de la misma. En este sentido los autores de cómic cuidan la letra escrita del mismo modo que el trazo de su dibujo, ya que ambos están dotados de cualidades expresivas dado que son formas gráficas. La letra, obviamente, va más allá pues genera un significante al formar palabras y frases.
} 


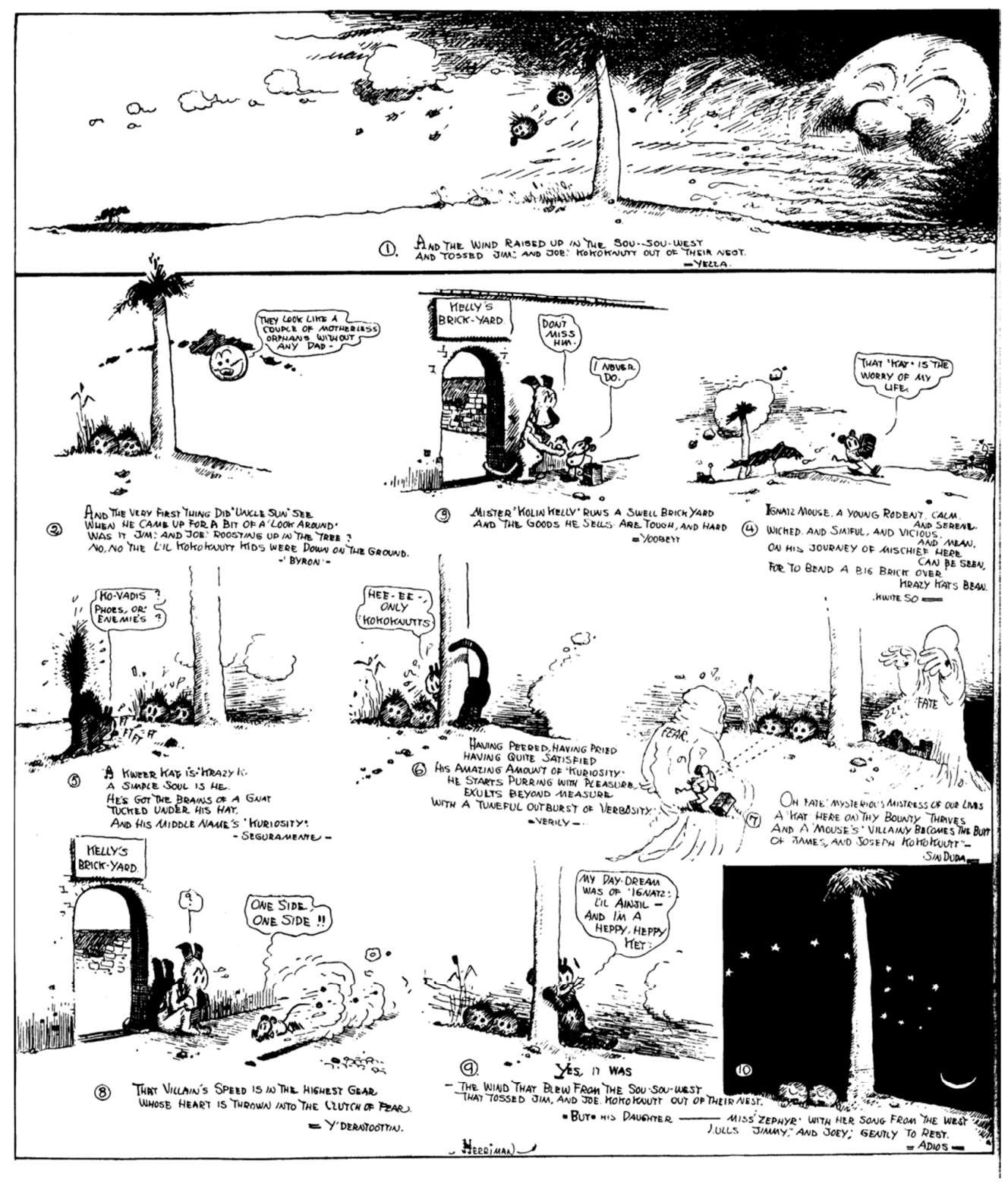

FIG. 7. Krazy Kat. George Herriman, 1916.

Como vemos en los dos últimos ejemplos, en las primeras décadas del siglo XX se ha trascendido definitivamente el tanteo por motivos prácticos de los pioneros para adentrarnos plenamente en un modo consciente de entender la historieta como una conjunción equilibrada de diferentes elementos. Equilibrada, narrativa y estética.

Krazy Kat nos sirve además para introducir otro concepto, para el que debemos adentrarnos brevemente en la historia y los personajes. Básicamente este cómic

CuCo, Cuadernos de cómic número 1. Septiembre de 2013 
desarrolla chistes de una página sobre tres protagonistas fijos (con un generoso elenco de secundarios). Todo pivota en torno a Krazy, un gato o gata ${ }^{14}$ enamorado de un ratón, Ignatz, el cual desprecia al felino y se lo manifiesta a ladrillazos... que el minino considera pruebas de amor. No así el agente de la ley, el cánido Ofissa Pupp, que generalmente interpreta la agresión en términos legales. Esto le lleva a detener al roedor no diremos en cada gag, pero sí muy a menudo. Queda claro entonces que hay un acto recurrente en estas historias: ese ladrillazo de tintes sadomasoquistas propinado por Ignatz a Kat, ${ }^{15}$ que como vemos en la FIG. $\underline{8}$, se plasma gráficamente con el empleo de onomatopeyas.

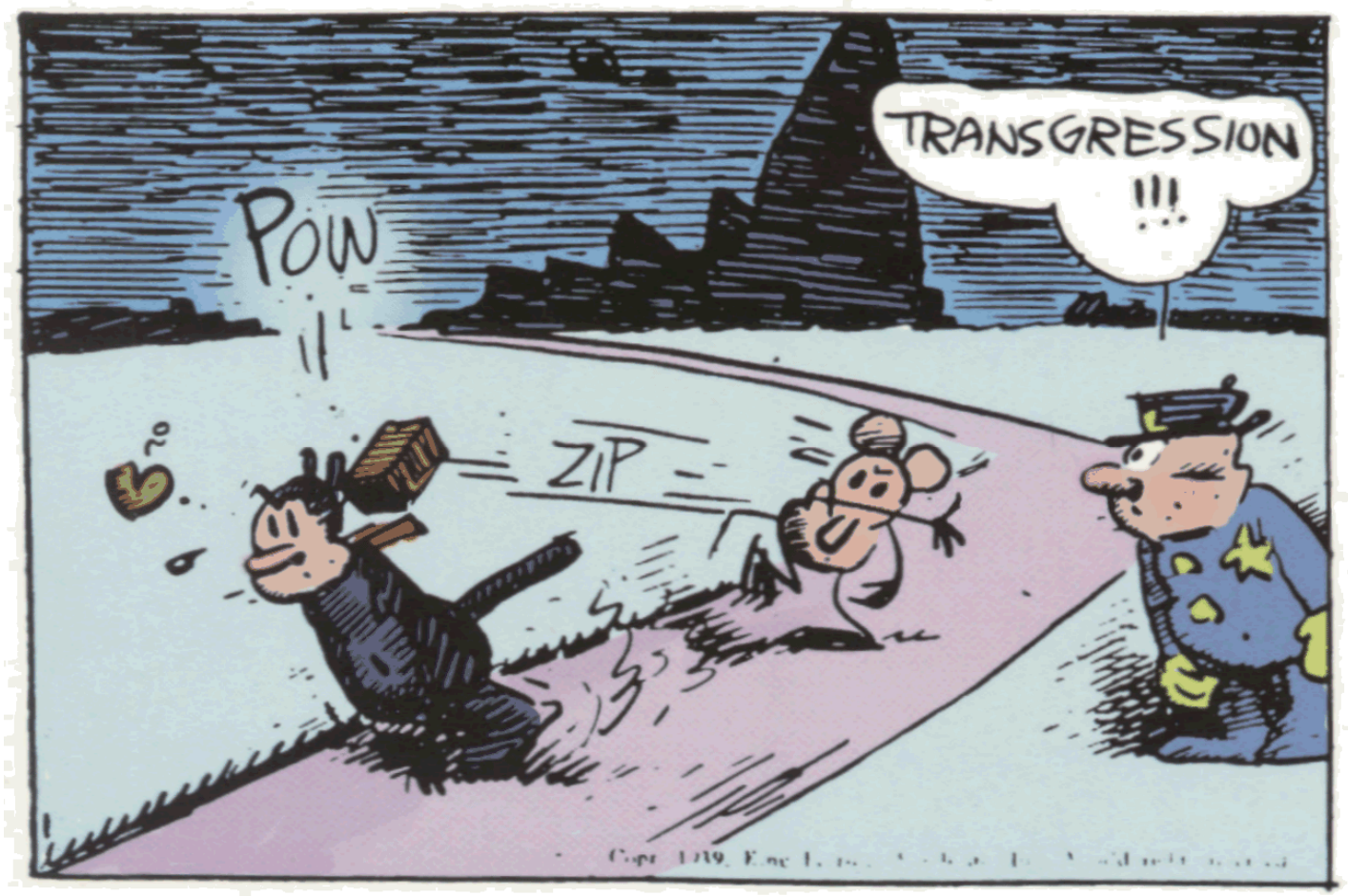

FIG. 8. Krazy Kat. George Herriman, 1939. Krazy recibe un ladrillazo. Detalle de plancha.

\footnotetext{
${ }^{14}$ Dijo George Herriman respecto al género esquivo de su criatura "Krazy es como un espíritu, como un elfo, no tiene sexo. De modo que no puede ser femenino o masculino" (Herriman 1983, 34), en CoMA, J. (coord.). Historia de los cómics. Vol. 1, Barcelona, Toutain editor, 1983, p. 34.)

${ }^{15}$ Sadomasoquismo poco encubierto: el ratón disfruta de su agresión sistemática a golpe de adoquín, y Krazy lo recibe con alborozo, interpretándolo como signo de amor.
}

CuCo, Cuadernos de cómic número 1. Septiembre de 2013 
Es la primera vez que introducimos este concepto en nuestro discurso. La onomatopeya consiste, en definición del Diccionario de la Real Academia, en la "imitación o recreación del sonido de algo en el vocablo que se forma para significarlo", siendo también el "vocablo que imita o recrea el sonido de la cosa o la acción nombrada". Golpes, ruidos indeterminados o de procedencia animal, incluso acciones físicas que o bien están consensuadas (piénsese en un ladrido, "guau”), o bien son creadas por la imaginación del artista. En el ejemplo de la $\underline{\text { FIG. } 8}$ el lanzamiento de ladrillo se describe, además de mediante líneas cinéticas, con un ZIP, y la exitosa colisión con la cabeza de Krazy, mediante un POW.

Es interesante ahora retornar al momento ya analizado en que Nemo, en la plancha de Little Nemo in Slumberland (FIG. 6), cae al lago de salsa de arándanos. Y ponerlo en relación con otra zambullida, la de la FIG. 9, perteneciente a Mutt y Jeff, de Bud Fisher, de 1910.

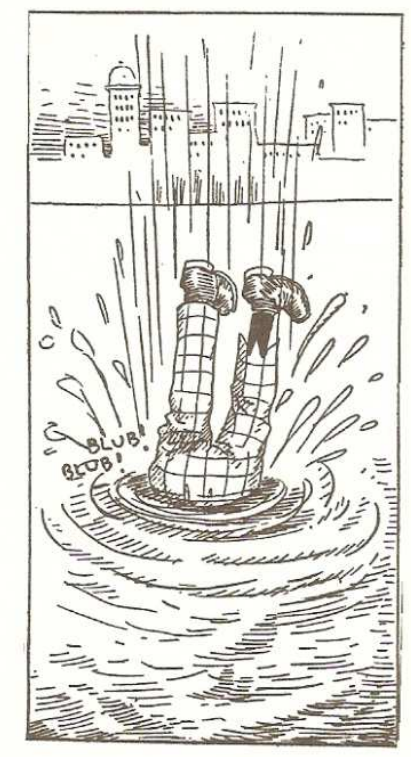

FIG. 9. Mutt y Jeff, Bud Fisher, 1910.

En los inicios de la historieta los recursos y soluciones son tanteados, aplicados puntualmente pero aún no sistematizados. Hemos visto cómo en un determinado momento Outcault utilizó globos y viñetas desde el 25 de Octubre de 1896 (FIG. 5), 
pero abandona la idea al día siguiente, cual si se tratase de una simple ocurrencia. Sin embargo en Krazy Kat, obra nacida en 1916 y que se publicó en el New York Herald hasta 1955, encontramos un arte ya asentado y autoconsciente de sus rasgos más básicos. Retrocedamos nuevamente en el tiempo y en nuestros ejemplos. En las planchas de Little Nemo in Slumberland aún conviven los refinamientos con modos formales poco evolucionados (en el ejemplo que hemos usado, de 1905, podemos comprobar la ausencia de onomatopeya). Es curioso ver cómo McCay, sin duda un autor de gran sofisticación, ${ }^{16}$ no tienta el empleo de una onomatopeya para potenciar la caída del niño en el mar, mientras que Bud Fisher (1885-1954) en la FIG. 9, de 1910, entiende la pertinencia del recurso. No hay en esta imagen de Mutt y Jeff sino un empleo discreto de la solución, apenas descriptivo. Se enfatiza un hecho, la caída al agua del personaje, a través de la palabra BLUB, repetida y con exclamaciones. Aún no estamos en un empleo gráficamente expresivo del recurso textual, cuya caligrafía resulta aquí muy discreta, poco icónica; pero sí ante la conciencia por parte de su autor de que existe y de que su uso es pertinente. En Krazy Kat, obra posterior a Mutt y Jeff, no solo resulta oportuno sino que se sistematiza, como ya hemos dicho, el ilustrar el ladrillazo con onomatopeyas. En esa pautada recurrencia el signo escrito adquiere connotaciones de expresividad narrativa. En la FIG. 8 por su forma, por su “dibujo", la letra nos narra, cuenta algo, nos transmite información de la historia: es una letra grande, en mayúsculas, con lo que explica la contundencia del suceso. $\mathrm{Y}$ en tanto que modo narrativo recurrente, el recurso de usar onomatopeyas para describir lanzamiento y ladrillazo una y otra vez en Krazy Kat llegará a identificarse como un momento de humor por repetición y reconocimiento inmediato, semana tras semana, plancha tras plancha.

16 Winsor McCay, por su dibujo emparentado con el modernismo y la revolución de la arquitectura urbana, así como por su gusto hacia lo onírico, se hermana con las artes de su tiempo o incluso avanza tendencias artísticas como el surrealismo. Por su inventiva en la narración, el empleo enormemente imaginativo del diseño de página y la deconstrucción de la viñeta, su obra aún hoy se nos presenta moderna. 
Podríamos crear un paréntesis aclaratorio, y reconocer que la obra de Herriman es visionaria, absolutamente avanzada para su tiempo. Se trata de un cómic que aún hoy deja huella estilística en no pocos autores. ${ }^{17}$ Pero también hay que resaltar la función aleccionadora del caso analizado y subrayar que tanto la obra de Herriman como los demás ejemplos ya vistos los entendemos como paradigmas de su tiempo. Son buena muestra de una evolución general de la historieta como medio artístico, de la aparición de los diferentes recursos gráficos y sobre todo, en tanto que eje del presente estudio, textuales. Cada uno de estos cómics es hijo de su tiempo, y lo identifica más allá de constituir, que también, una obra única, excepcional y en ocasiones visionaria.

En estas fechas tempranas, en definitiva, la historieta es un campo de pruebas. Los autores van utilizando la letra escrita de un modo acaso intuitivo, pero en busca de convertir un hecho mecánico o funcional (aunque en el siglo XIX revolucionario) en algo estético e inventivo. Durante las primeras décadas del siglo XX la letra, lo hemos visto, se beneficia de caligrafías cada vez más refinadas, y a la vez empieza a experimentarse con la grafía como forma y como mensaje, donde un texto en un cómic implica una serie de contenidos según su plasmación y, lo veremos más adelante, color.

En la FIG. 10, perteneciente a Spare ribs and Gravy de Georges McManus (18841954) y publicada en 1909, tenemos un buen ejemplo al respecto, al menos en lo que a la forma concierne. En la primera viñeta dos individuos "civilizados" enfrentan el dilema de cómo cruzar un río, y la solución la aporta un aborigen, que llama a gritos a un hipopótamo situado presumiblemente lejos, en la otra vertiente del río, en la otra orilla. El tamaño de la letra se duplica para ilustrar ese expresivo llamamiento (WAHOO!), en relación al resto del diálogo de la escena. Con el aumento del tamaño de la fuente, McManus refleja el acto de vocear.

\footnotetext{
${ }^{17}$ De hecho uno de los más contemporáneos y relevantes autores de historieta, Chris Ware, no solamente ha reconocido dicho influjo (y se aprecia en su obra) sino que ha diseñado personalmente las portadas de la última reedición de Krazy Kat para la editorial estadounidense Fantagraphics.
}

CuCo, Cuadernos de cómic número 1. Septiembre de 2013 

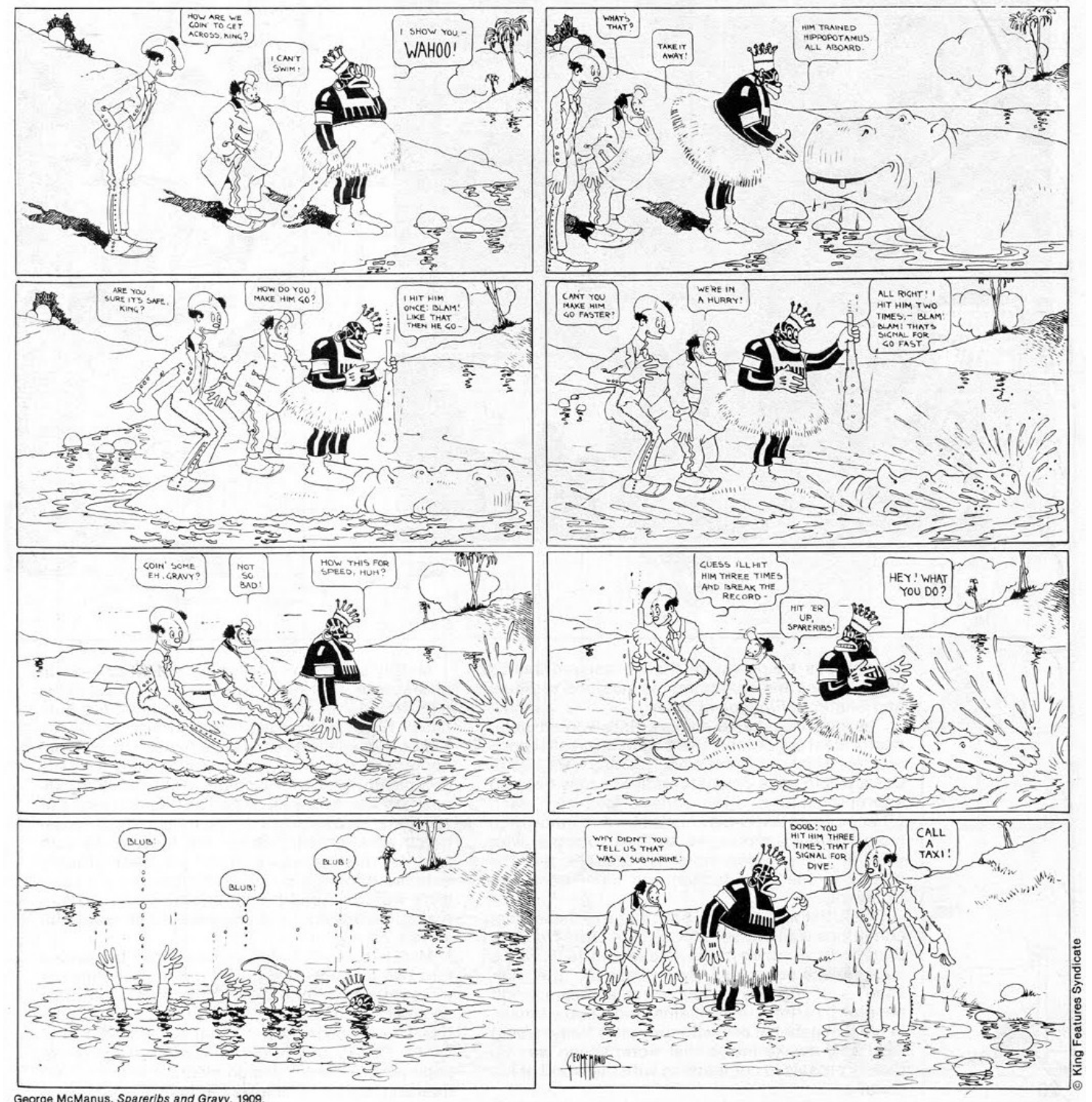

FIG. 10. Spare ribs and Gravy. George McManus, 1909.

Otro ejemplo puede ilustrar cómo forma y ahora también color de la fuente son recursos propios del cómic que van añadiéndose al acervo de los autores, pasando de tanteos singulares a modos recurrentes: es la FIG. 11, una escena perteneciente a The Gumps, obra creada por Sidney Smith (1877-1935) en 1917 y desarrollada hasta 1959 por diversos autores. En este caso, la viñeta data de 1924 y pertenece a su creador. En la imagen se describe un "simple" pinchazo.

CuCo, Cuadernos de cómic número 1. Septiembre de 2013 


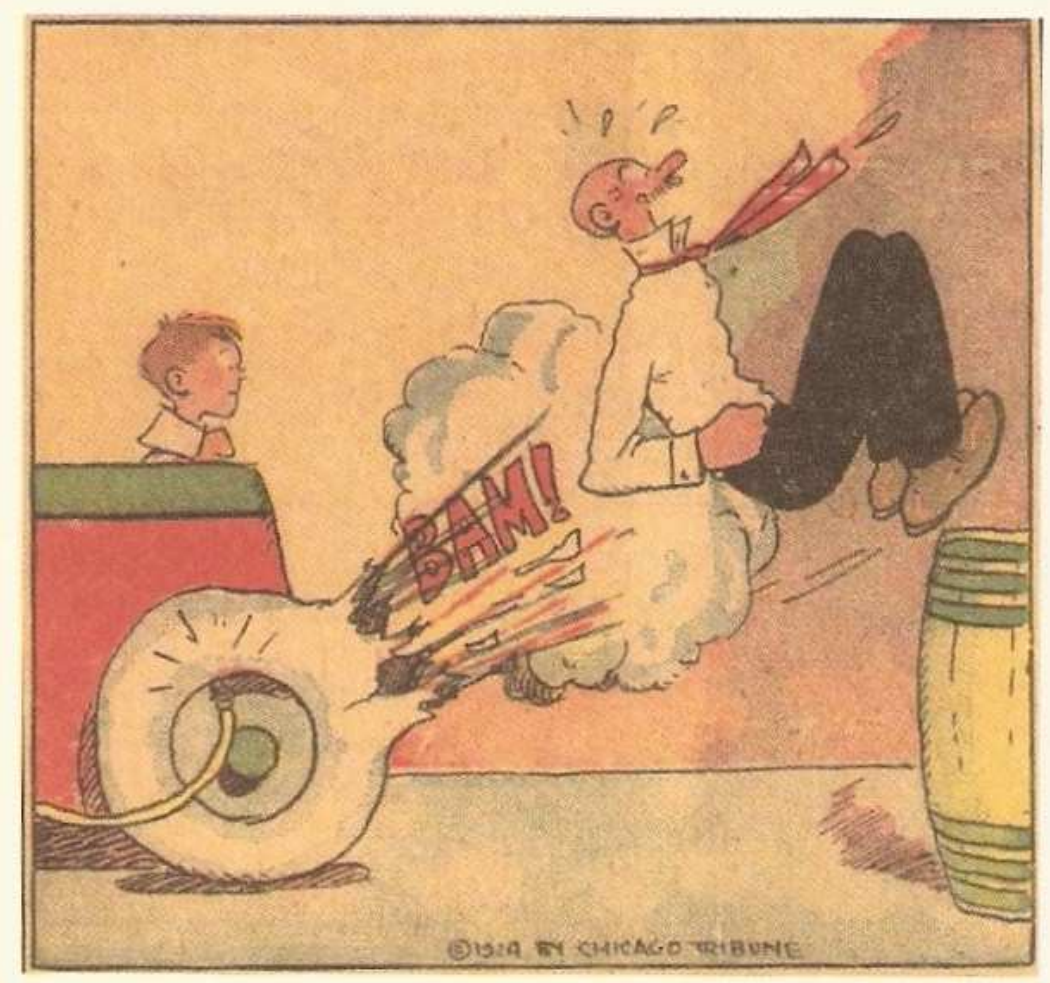

FIG. 11. The Gumps. Sydney Smith, 1924.

Lejos del modelo funcional del chapoteo en Mutt y Jeff de la FIG. 9, y más aún de la ausencia de onomatopeya de la FIG. 6 de Winsor McCay, el reventón, al tratarse además de una página a color, ${ }^{18}$ se enfatiza con diversos recursos. Por un lado, el BAM se escribe a gran tamaño, se ubica como centro físico de la imagen encuadrada en la viñeta, se dibuja con una línea curva pero de vértices angulosos, cortantes, y sobre todo se elige un intenso color rojo para potenciar el efecto narrativo. Podemos advertir un grado de complejidad muy evolucionado en este ejemplo, y esa evolución se ha recorrido en unos pocos lustros, si pensamos que el cómic comienza a ser

\footnotetext{
${ }^{18}$ La historieta norteamericana, originalmente ubicada en la prensa diaria hasta su emancipación en los años treinta con el formato de la revista de comic-books, se publicaba diariamente en tiras en blanco y negro, reservándose una página dominical para el lucimiento a color. Es la tradicional división entre las daily strips o tiras diarias y las Sundays o dominicales. Modelo que pervive hasta nuestro presente, pese a que hoy existen diversos cauces y formatos de edición para la historieta.
} 
autoconsciente aproximadamente en el cambio de siglo y no antes. De hecho podríamos hacernos una pregunta. ¿Hablamos de un cierto esplendor en los años veinte?

Con la historieta asentada en el mercado y en el imaginario de la cultura de masas occidental, a finales de la tercera década del siglo XX el lenguaje del cómic parece ya definido, y sin embargo en esta situación de aparente culmen se producirá un avance acaso revolucionario que lleva al cómic a su Edad de Oro. Javier Coma identifica en su Diccionario de los cómics: la Edad de Oro $^{19}$ dicho momento áureo como "una evolución hacia horizontes estilísticos y narrativos más amplios". Y añade "a lo largo de los años treinta, las páginas de cómic en los diarios ofrecían una vastísima gama de géneros temáticos, estructuras narrativas, estilos gráficos y enfoques del arte y la vida". 20

En esta época, en Estados Unidos pronto los diarios que albergan las tiras más destacadas comienzan a tantear una posibilidad de clara intención comercial. Si hasta los años veinte del siglo pasado cada tira diaria y cada página del dominical venían a ilustrar en sí misma una breve historia (de carácter humorístico generalmente), ¿por qué no perpetuar una narración-río al modo folletinesco? Crear un argumento que no se acota a las cuatro o cinco viñetas de una tira de prensa o a la página a todo color de un domingo, sino que proponga una situación que deberá concluirse en la tira o plancha dominical que la prosiga, es un modo de fidelizar compradores del diario o la revista. Y así sucedió, efectivamente, ${ }^{21}$ y se demostró que la idea conlleva un firme gancho comercial. Pero además propicia la evolución del medio, porque evidentemente el ardid se ligó a la aparición de nuevos géneros narrativos. Si en los primeros años del cómic la sátira y el humor eran la tónica dominante, el recurso de la continuidad atrae

\footnotetext{
${ }^{19}$ ComA, J. Diccionario de los cómics: la Edad de Oro. Plaza \& Janés, 1991.

${ }^{20}$ Ibíd., p. 19.

${ }^{21}$ La continuidad, como es lógico, no surgirá repentinamente sino que existen ensayos previos. De hecho, ya hemos visto uno al citar Little Nemo in Slumberland de Winsor McCay, quien si bien cerraba cada plancha con el despertar de Nemo, la ensoñación, la aventura en el País de los Sueños, solía continuarse de una Sunday a la siguiente, creando esa sensación de continuidad.
} 
argumentos donde lo intrépido, la aventura, el peligro o el drama cobran protagonismo. Es fácilmente comprensible que la idea de perpetuar un gag o una situación cómica en las tiras diarias de la prensa carece de gancho, pero sí lo tiene presentar una aventura en rincones exóticos que se interrumpe en medio de un terrible peligro... que se resolverá mañana en las páginas del mismo diario. O más bien que nos devolverá un nuevo avatar a resolver al día siguiente.

Con la continuidad como ardid narrativo en la historieta llegamos a un momento de madurez donde caben los estilos y los géneros más variopintos. ${ }^{22} \mathrm{El}$ final de los años veinte y la década de los treinta se enriquecen con numerosos cómics de acción, aventuras, detectives y criminales, ciencia ficción o aventura histórica hasta llegar a un nuevo momento clave en la historia del medio, con la aparición del comic-book y los superhéroes en Estados Unidos (que amalgaman un poco de todo ello: drama y aventura, ciencia ficción y policíaco, humor y acción, exotismo y costumbrismo). Y esta explosión creativa y temática se aprecia en obras como las aventuras del Wash Tubbs (1924) de Roy Crane, la ciencia ficción de Buck Rogers (1928), creado por Philip Francis Nowlan, Dick Tracy (1931) de Chester Gould o la saga histórica de Príncipe Valiente (1937) de Harold Foster. ${ }^{23}$ O Superman (1938) de Jerry Siegel y Joe Shuster y sus numerosas réplicas superheroicas, que además supusieron el éxito, por primera vez, de un soporte específico para el medio como es el cuadernillo grapado que contiene las aventuras de un único personaje, el ya citado comic-book. Además, esta explosión de creatividad contagia al mercado europeo también (o simplemente es coetánea), con una apertura del espectro temático y la aparición de los más grandes iconos del cómic europeo. $^{24}$

\footnotetext{
${ }^{22}$ Una primera madurez en un proceso continuo de cambios, búsquedas y crecimiento que se perpetúa hasta nuestros días, por supuesto, antes que un cénit insuperado

${ }^{23}$ Príncipe Valiente es un caso curioso ya que, en aras de potenciar su espectacular dibujo realista, prescinde de elementos escritos dentro de sus viñetas, de modo que lo textual se reduce a didascalias.

${ }^{24}$ No es casual que 1930, plena Edad de Oro del cómic, sea el año en que nace el mayor icono de la historieta europea, Tintín, de Hergé (1907-1983), en las páginas de la revista infantil Coeurs Vaillants, y
}

CuCo, Cuadernos de cómic número 1. Septiembre de 2013

CuCoEstudio 
Tenemos el convencimiento de que un repaso histórico para el objeto de nuestro estudio no debe ir más allá de este punto, los inicios de esta llamada Edad de Oro de los tebeos. ${ }^{25}$ Es un tiempo que supone por tanto la culminación de un modelo en los años treinta del pasado siglo, crecido las décadas anteriores y aportando un estado de enorme diversidad a la historieta. El crecimiento y multiplicidad de escuelas, estilos, géneros y formatos de edición, avanza a partir de entonces en un crisol de posibilidades, también en los aspectos formales, antes que en una linealidad más propia de los estados primigenios o de la incipiencia artística. Por tanto a partir de este punto será más fructífero para nuestro estudio observar la variedad antes que la cronología. Será un buen momento en este análisis para trascender la mirada temporal y lineal, y profundizar en el estudio formal de nuestro foco de atención.

La letra escrita en un medio de narración por imágenes ha germinado de un modo natural en el cómic, imbricada la palabra a la imagen narrativa, y ha provocado con su desarrollo una gran variedad tipológica y formal, así como una riqueza en sus capacidades expresivas y de contenidos.

Continuaremos nuestro estudio en este sentido en venidera entregas, analizando la grafía en la historieta desde varias perspectivas: modos de reproducción, ubicación en la página, propiedades narrativas y estética de la grafía. Y para ello, atenderemos a ejemplos de diversas épocas, ya sin un sentido cronológico, en $\mathrm{CuCo}$, Cuadernos de cómic n. ${ }^{\circ} 2$.

por tanto en origen una obra evidentemente de continuidad y del género aventurero, que además supone una escuela estética renovadora, la línea clara.

${ }^{25}$ Hay que valorar aquí el hecho de que, según fuentes e historiadores, la Edad de Oro podría centrarse en el esplendor de la continuidad en los cómics de prensa, o bien en el momento en que irrumpe y se consolida el comic-book entre los años treinta y los cincuenta. Sea como fuera, nosotros pensamos que se habla de un mismo periodo, un hiato temporal que enriquece al noveno arte de un modo plural, tanto por la proliferación de diferentes estilos como de géneros y formatos de edición. 